\title{
MENINGKATKAN HASIL BELAJAR SISWA PADA PEMBELAJARAN IPS MATERI TOKOH-TOKOH SEJARAH HINDU - BUDHA DAN ISLAM MELALUI MODEL PEMBELAJARAN KOOPERATIF TIPE STUDENT TEAMS ACHIEVEMENT DIVISION (STAD) KELAS III SD NEGERI 1 SIONTAPINA
}

\author{
Siti Sarliati, Gawise \\ Fakultas Keguruan dan Ilmu Pendidikan, Universitas Muhammadiyah Buton \\ Email :gawiseumb71@gmail.com
}

\begin{abstract}
Abstrak : Penelitian ini bertujuan untuk mengetahui peningkatan hasil belajar siswa melalui model pembelajaran kooperatif tipe Student Teams Achievement Division (STAD) pada pembelajaraan IPS materi tokoh-tokoh sejarah Hindu-Budha dan Islam kelas III SDN 1 Siontapina. Penelitian ini dilakukan dengan menggunakan metode Penelitian Tindakan Kelas (PTK). Penelitian tindakan kelas ini dilakukan sebanyak dua siklus, masing-masing siklus dilaksanakan dua kali petemuan disesuaikan dengan jadwal pelajaran IPS yang ada di sekolah. Setiap siklus terdiri dari empat tahap yaitu perencanaan, pelaksanaan tindakan, observasi dan refleksi. Sasaran penelitian ini adalah siswa kelas III SD Negeri 1 Siontapina. Teknik pengumpulan data diperoleh dari hasil penilaian awal dan hasil penilaian individu siswa. Kesimpulan dari penelitian ini adalah model pembelajaran kooperatif tipe Student Teams Achievement Division (STAD) ternyata merupakan salah satu metode yang dapat diterapkan dalam pembelajaran IPS. Penggunaan model kooperatif tipe STAD dalam pembelajaran IPS dapat meningkatkan hasil belajar siswa di sekolah terutama di SD Negeri 1 Siontapina. Hasil tersebut dapat dilihat dari ketercapaian nilai KKM siswa dan persentase yang mengalami peningkatan dari penilaian awal sebesar 25\%, siklus I sebesar 56,3\%, dan pada siklus II sebesar 87,50\%. Jadi, peningkatan hasil belajar siswa dalam pembelajaran IPS melalui model kooperatif tipe STAD masing-masing sebesar $31,3 \%$. Hasil tersebut menunjukan bahwa pada penilaian awal dan siklus I dikatakan belum tuntas karena siswa yang memperoleh nilai $\geq 70$ hanya sebesar $25 \%$ dan $56,3 \%$ lebih kecil dari persentase ketuntasan yang diharapkan yakni $80 \%$. Pada siklus II hasil belajar siswa dikatakan tuntas karena siswa yang memperoleh nilai $\geq 70$ sebesar $87,3 \%$ sudah melebihi persentase ketuntasan yang diharapakan yaitu $80 \%$.
\end{abstract}

Kata Kunci: Meningkatkan Hasil Belajar Siswa Melalui Model Pembelajaran Kooperatif tipe Student Teams Achievement Division (STAD)

\section{LATAR BELAKANG}

Pendidikan memerankan peran yang sangat penting dalam membentuk kualitas suatu bangsa. Menyadari akan hal tersebut, pemerintah sangat serius menangani bidang pendidikan. Sistem pendidikan nasional diharapkan harus mampu menjamin peningkatan mutu dan efisiensi manajemen pendidikan untuk menghadapi tantangan sesuai dengan tuntutan perubahan kehidupan lokal, nasional dan global sehingga 
perlu dilakukan pembaharuan pendidikan secara terencana, terarah dan berkesinambungan. Dalam Undang - Undang No. 20 Tahun 2003 pasal I ayat I tentang Sistem Pendidikan Nasional dinyatakan Pendidikan adalah usaha sadar dan terencana untuk mewujudkan suasana belajar dan proses belajar agar peserta didik secara aktif membangun potensi dirinya untuk memiliki kekuatan spiritual keagamaan, pengendalian diri, kepribadian, kecerdasan, akhlak mulia serta ketrampilan yang diperlukan dirinya, masyarakat, bangsa dan Negara.

Keberhasilan penyelenggaraan pendidikan dapat dipengaruhi oleh beberapa faktor salah satunya adalah kesiapan guru dalam mempersiapkan peserta didik melalui proses pembelajaran. Penggunaan metode yang tepat akan menjadikan siswa secara efektif mampu menerima pesan yang disampaikan. Menurut Rukmini (2004 : 99) orang yang belajar akan bertambah pengetahuannya yang berarti tahu lebih banyak daripada sebelum belajar.

Praktek pendidikan saat ini selain ditandai oleh peran guru yang dominan juga ditandai dengan siswa yang hanya menghafalkan materi pelajaran. Hal ini sering terjadi pada proses pembelajaran materi Ilmu Pengetahuan Sosial (IPS). Siswa masih menganggap hanya dengan menghafal mereka dapat menguasai suatu konsep untuk mendapat hasil belajar yang maksimal. Sedangkan menurut Saripudin (1989:2), Ilmu Pengetahuan Sosial (IPS) merupakan salah satu mata pelajaran yang dirancang dan dilaksanakan untuk mengembangkan karakteristik siswa dalam cara berfikir, bersikap, dan berperilaku sosial untuk hidup bermasyarakat menjadi warga negara Indonesia yang baik.

Tuntutan dalam dunia pendidikan sudah banyak berubah, sehingga perlu adanya pembaharuan model pembelajaran terutama pada mata pelajaran Ilmu Pengetahuan Sosial (IPS). Salah satu model pembelajaran saat ini yang banyak mendapat respon namun belum banyak dilaksanakan dalam dunia pendidikan secara optimal adalah model pembelajaran kooperatif.

Menurut Suprijono (2010:61), "model pembelajaran kooperatif dikembangkan untuk mencapai hasil belajar berupa prestasi akademik, toleransi, menerima keragaman, dan pengembangan keterampilan sosial". Dengan model pembelajaran ini, siswa berkesempatan untuk berkomunikasi dan berinteraksi sosial dengan siswa yang lain. Walaupun terdapat keberagaman antarsiswa, namun akan terjadi persaingan yang positif dalam rangka untuk mencapai prestasi belajar Ilmu Pengetahuan Sosial (IPS) yang optimal. Sedangkan guru dalam pembelajaran ini bertindak sebagai motivator dan fasilitator aktivitas siswa.

Berdasarkan hasil observasi awal di kelas III SD Negeri 1 Siontapina, terdapat beberapa informasi yang dapat mendukung penelitian. Siswa kelas III di SD Negeri 1 Siontapina kurang dilibatkan secara aktif dalam proses pembelajaran. Siswa hanya mendengarkan penjelasan dari guru dan hanya sesekali mencatat materi. Hal ini menyebabkan siswa belum secara maksimal mengembangkan kemampuan dalam berpikir, bersikap dan berketerampilan. Siswa masih pasif, kurang memperhatikan guru dan kurang berpartisipasi dalam proses pembelajaran. 
Kondisi seperti dijelaskan di atas jelas berdampak kurang baik terhadap siswa. Berdasarkan data nilai siswa pada mata pelajaran Ilmu Pengetahuan Sosial (IPS), dapat dikatakan bahwa prestasi belajar siswa relatif rendah. Nilai rata-rata di bawah nilai Kriteria Ketuntasan Minimal (KKM) yaitu 70.

Salah satu model pembelajaran yang inovatif dalam menghadapi tuntutan dunia pendidikan adalah pembelajaran kooperatif, yang mencakup suatu kelompok kecil siswa yang bekerja sebagai sebuah tim untuk menyelesaikan sebuah masalah, menyelesaikan suatu tugas atau untuk mengerjakan sesuatu untuk mencapai tujuan bersama lainnya. Salah satu contoh model pembelajaran kooperatif adalah STAD (Student Teams Achievement Divisions). Inti dari STAD adalah guru menyampaikan suatu materi, kemudian para siswa bergabung dalam kelompoknya yang terdiri atas empat atau lima orang yang merupakan campuran menurut tingkat prestasi, jenis kelamin, dan suku untuk menyelesaikan soal-soal yang diberikan oleh guru dan memastikan bahwa seluruh anggota tim telah menguasai pelajaran tersebut. Setelah selesai siswa menyerahkan pekerjaannya secara tunggal untuk setiap kelompok kepada guru. Tim yang mendapat skor tertinggi mendapat penghargaan, kemudian seluruh siswa diberi kuis tentang materi tersebut.

Pembelajaran kooperatif tipe STAD tidak sama dengan sekedar belajar dalam kelompok. Unsur-unsur dasar pembelajaran kooperatif tipe STAD yang membedakannya dengan pembagian kelompok yang dilakukan asal-asalan. Pelaksanaan prosedur model pembelajaran kooperatif tipe STAD dengan benar akan memungkinkan guru mengelola kelas lebih efektif. Selain itu juga siswa akan menjadi lebih aktif dalam belajar karena akan selalu berinteraksi dengan teman-teman yang lain dalam mengerjakan tugas maupun dalam melakukan percobaan-percobaan yang sangat diperlukan dalam pembelajaran Ilmu Pengetahuan Sosial (IPS).

Berdasarkan kondisi tersebut, maka perlu dilakukan penelitian untuk mengetahui lebih lanjut Peningkatan Hasil Belajar Siswa pada Pembelajaran IPS Materi Tokoh-Tokoh Sejarah Hindu Budha dan Islam Melalui Model Pembelajaran Kooperatif Tipe Student Teams Achievement Division (STAD) Kelas III SD Negeri 1 Siontapina.

\section{METODE PENELITIAN}

Penelitian ini merupakan penelitian tindakan kelas (PTK). Penelitian ini bertujuan untuk mengetahui peningkatan hasil belajar siswa melalui model pembelajaran kooperatif tipe Student Teams Achievement Division (STAD) pada pembelajaraan IPS materi tokoh-tokoh sejarah Hindu-Budha dan Islam kelas III SDN 1 Siontapina. Desain tindakan/rancangan siklus yang dipilih dalam penelitian tindakan ini mengikut prosedur penelitian tindakan kelas yang berawal dari perencanaan, pelaksanaan, observasi, dan refleksi. Teknik pengumpulan data dilakukan melalui observasi atau pengamatan, tes, wawancara, dan dokumentasi.

\section{HASIL PENELITIAN}

\section{Tindakan Awal}

Penelitian ini diawali dengan kegiatan wawancara awal dengan guru kelas III SD Negeri 1 Siontapina dan observasi awal pada tanggal 8 Mei 2017. Hasil observasi awal peneliti, 
menunjukkan bahwa siswa-siswa SD Negeri 1 Siontapina khususnya kelas III masih kurang aktif dan kurang perhatiannya dalam proses pembelajaran. Pada saat proses belajar mengajar berlangsung. Menurut guru tersebut diperlukan model pembelajaran yang dapat memotivasi dan meningkatkan minat serta peran aktif siswa dalam belajar, khususnya pada pelajaran IPS. Sementara hasil observasi awal peneliti pada tanggal 8 Mei 2017 menunjukkan bahwa hasil belajar IPS siswa kelas III masih rendah. Berdasarkan hasil observasi awal dan wawancara tersebut, maka peneliti memutuskan untuk menguji cobakan metode pembelajaran yang dapat memotivasi siswa serta meningkatkan peran aktif siswa dalam proses pembelajaran, yang diharapkan dapat meningkatkan hasil belajar siswa. Metode pembelajaran yang dipilih adalah metode kooperatif tipe Student Team Achievement Division (STAD) dalam mengajarkan IPS materi tokohtokoh sejarah Hindu-Budha dan Islam pada kelas III SD Negeri 1 Siontapina.

Selanjutnya pada tanggal 15 Juni 2017 diadakan tes awal pada siswa kelas III SD Negeri 1 Siontapina untuk mengetahui kemampuan kognitif siswa terhadap materi tokoh-tokoh sejarah Hindu-Budha dan Islam. Nilai awal tersebut dijadikan sebagai acuan untuk mengetahui hasil peningkatan belajar siswa kelas III SD Negeri 1 Siontapina selama penerapan model kooperatif tipe Student Team Achievement Division (STAD) diterapkan.

Soal-soal tes awal berupa materi prasyarat atau materi yang berhubungan dengan pokok bahasan tokoh-tokoh sejarah Hindu-Budha dan Islam. Berdasarkan hasil tes awal yang diperoleh siswa secara klasikal hanya mencapai $25 \%$ dengan nilai rata-rata ketuntasan hasil belajar siswa ada tes awal sebesar 60. Hal ini memberi gambaran bahwa pengetahuan siswa terhadap tokoh-tokoh sejarah HinduBudha dan Islam masih kurang.

\section{Siklus I}

Siklus I dilaksanakan pada tanggal 16 dan 23 Agustus 2017. Persentase ketuntasan siswa dalam mengerjakan tes Individu dapat dilihat pada tabel 1 berikut ini:

\section{Tabel 1}

\section{Persentase Ketuntasan}

Hasil Belajar Individu Siswa Siklus I

\begin{tabular}{|l|c|c|}
\hline \multicolumn{1}{|c|}{ Keterangan } & Jumlah & $\begin{array}{c}\text { Persentas } \\
\text { e }\end{array}$ \\
\hline $\begin{array}{l}\text { Siswa yang } \\
\text { mencapai } \\
\text { KKM }\end{array}$ & 9 & $56,30 \%$ \\
\hline $\begin{array}{l}\text { Siswa yang } \\
\text { tidak } \\
\text { mencapai } \\
\text { KKM }\end{array}$ & 7 & $43,70 \%$ \\
\hline \multicolumn{1}{|l|}{ Jumlah } & 16 & $100 \%$ \\
\hline $\begin{array}{l}\text { Ketuntasan } \\
\text { belajar } \\
\text { individu yang } \\
\text { dicapai siswa } \\
\text { ketuntasan } \\
\text { belajar } \\
\geq 50 \% \text { ) }\end{array}$ & $56,30 \%$ \\
\hline
\end{tabular}

Dari tabel 1 di atas dapat dijelaskan bahwa dengan menerapkan metode pembelajaran kooperatif tipe Student Teams Achievement Division (STAD) diperoleh nilai rata-rata hasil penilaian akhir siswa adalah 69,7 dan ketuntasan belajar mencapai 56,3\% atau ada 9 siswa dari 16 siswa yang tuntas belajar dan 7 siswa yang tidak tuntas belajar. Hasil tersebut menunjukan bahwa pada siklus I secara 
klasikal belum tuntas belajar, karena siswa yang memperoleh nilai $\geq 70$ hanya sebesar 56,3\% lebih kecil dari persentase ketuntasan yang diharapkan yaitu sebesar $80 \%$. Hal ini disebabkan karena siswa masi merasa baru dan belum mengerti apa yang dimaksudkan dan digunakan oleh peneliti dengan menerapkan model kooperatif tipe Student Teams Achievement Division (STAD).

\section{Siklus II}

Siklus II dilaksanakan pada tanggal 30 Agustus dan 6 September 2017. Persentase ketuntasan siswa dalam mengerjakan tes dapat dilihat pada tabel 2 berikut ini:

Tabel 2

Persentase Ketuntasan Hasil Belajar Individu Siswa Siklus II

\begin{tabular}{|l|c|c|}
\hline \multicolumn{1}{|c|}{ Keterangan } & Jumlah & $\begin{array}{c}\text { Persentas } \\
\mathrm{e}\end{array}$ \\
\hline $\begin{array}{l}\text { Siswa yang } \\
\text { mencapai } \\
\text { KKM }\end{array}$ & 14 & $87,50 \%$ \\
\hline $\begin{array}{l}\text { Siswa yang } \\
\text { tidak mencapai } \\
\text { KKM }\end{array}$ & 2 & $12,50 \%$ \\
\hline \multicolumn{1}{|c|}{ Jumlah } & 16 & $100 \%$ \\
\hline $\begin{array}{l}\text { Ketuntasan } \\
\text { belajar } \\
\text { individu yang } \\
\text { dicapai siswa } \\
\text { (ketuntasan } \\
\text { belajar } \geq 50 \% \text { ) }\end{array}$ & \multicolumn{2}{|l}{$87,50 \%$} \\
\hline
\end{tabular}

Berdasarkan Tabel 2 di atas dapat dianalisis sebagai berikut:

a Pada siklus II terdapat 14 siswa dari 16 siswa yang telah mencapai nilai KKM ( $\geq 70)$ dengan persentase $87,5 \%$. b. Pada sikus II terdapat 2 siswa dari 16 siswa yang belum mencapai KKM $(<70)$ dengan persentase $12,5 \%$.

Dari hasil observasi dan penilaian pada pelaksanaan Siklus II maka dapat ditarik kesimpulan yaitu nilai yang diperoleh siswa dari Siklus II sudah mengalami peningkatan. Persentase ketuntasan belajar siswa individu mencapai 87,50\% yang dicapai oleh 14 siswa yang berarti sudah melebihi kriteria keberhasilan yang sudah ditentukan yaitu $80 \%$, sehingga penelitian tidak perlu dilanjutkan lagi ke siklus berikutnya.

\section{PEMBAHASAN}

Penelitian ini menggunakan 2 siklus, masing-masing siklus dilakukan 2 kali pertemuan yang disesuaikan dengan jadwal pembelajaran.

Penerapan model pembelajaran kooperatif tipe STAD pada tes awal, siklus I, dan siklus II menunjukan adanya peningkatan hasil belajar siswa. Hasil belajar siswa mengalami kemajuan dari tes awal, siklus I, dan siklus II. Terbukti dengan adanya peningkatan jumlah siswa yang mencapai nilai di atas KKM. Peningkatan hasil belajar siswa ditunjukan dalam tabel 3 .

Tabel 3

\section{Perbandingan Peningkatan Hasil} Belajar Individu Siswa

\begin{tabular}{|l|c|c|c|}
\hline Keterangan & $\begin{array}{c}\text { Nilai } \\
\text { Awa } \\
1\end{array}$ & $\begin{array}{c}\text { Siklus } \\
\text { I }\end{array}$ & $\begin{array}{c}\text { Siklus } \\
\text { II }\end{array}$ \\
\hline $\begin{array}{l}\text { Jumlah siswa } \\
\text { yang } \\
\text { mencapai } \\
\text { KKM }\end{array}$ & 4 & 9 & 14 \\
\hline $\begin{array}{l}\text { Persentase } \\
\text { siswa yang }\end{array}$ & $25 \%$ & $\begin{array}{c}56,25 \\
\%\end{array}$ & $\begin{array}{c}87,50 \\
\%\end{array}$ \\
\hline
\end{tabular}




\begin{tabular}{|l|c|c|c|}
\hline $\begin{array}{l}\text { mencapai } \\
\text { KKM }\end{array}$ & & & \\
\hline $\begin{array}{l}\text { Rata-rata } \\
\text { Nilai }\end{array}$ & 60 & 69,7 & 81,6 \\
\hline
\end{tabular}

Berdasarkan tabel 3 di atas menunjukan peningkatan hasil belajar siswa dalam pembelajaran dengan model pembelajaran kooperatif tipe STAD. Pada tabel tersebut disebutkan bahwa jumlah siswa yang mencapai nilai KKM pada nilai awal sebanyak 4 siswa atau $25 \%$ dengan nilai rata-rata 60 dilanjutkan pada siklus I jumlah siswa yang mencapai nilai KKM sebanyak 9 siswa atau $56,25 \%$ dengan rata-rata nilai 69,7 dan terakhir Pada siklus II jumlah siswa yang mencapai nilai KKM meningkat menjadi 14 siswa atau $87,50 \%$ dengan rata-rata nilai 81,6 .

Berdasarkan hal di atas, dapat dikatakan bahwa penerapan metode pembelajaran Student Teams Achievement Division (STAD) pada Kelas III SD Negeri I Siontapina memberikan dampak positif terhadap peningkatan keaktifan siswa dan hasil belajar siswa. Mereka sudah mampu bersosialisasi dengan baik, bahkan sebagian besar siswa sudah berani mengeluarkan pendapatnya dan menjawab pertanyaan yang diberikan. Walaupun masih ada siswa yang memperoleh nilai dibawah standar atau yang dibawah nilai yang telah ditentukan berdasarkan indikator keberhasilan, namun mereka sudah memberikan penghargaan dan sikap positif pada saat model pembelajaran STAD diterapkan. berhubung indikator keberhasilan dalam penelitian ini telah tercapai, dalam hal ini minimal $80 \%$ siswa mencapai nilai minimal 70 (Kriteria Ketuntasan Minimal) maka penelitian ini dikatakan berhasil dan dihentikan pada siklus II.

\section{KESIMPULAN}

Berdasarkan hasil analisis pada penilaian awal, tindakan siklus I sampai dengan siklus II dari penelitian ini, dapat disimpulkan bahwa hasil belajar IPS siswa kelas III SD Negeri 1 Siontapina pada pokok bahasan tokohtokoh sejarah Hindu-Budha dan Islam dapat ditingkatkan melalui model pembelajaran kooperatif tipe Student Teams Achievement Division (STAD). Ini dapat dilihat dari hasil observasi, evaluasi, dan refleksi pada pelaksanaan setiap siklus diperoleh bahwa pada siklus I hasil belajar siswa meningkat dari $25 \%$ menjadi $56,3 \%$ atau naik sebesar 31,3\%, dan pada siklus II hasil belajar siswa meningkat menjadi $87,50 \%$ atau naik sebesar $31,3 \%$.

Hasil tersebut menunjukan bahwa pada penilaian awal dan siklus I dikatakan belum tuntas karena siswa yang memperoleh nilai $\geq 70$ hanya sebesar $25 \%$ dan 56,3\% lebih kecil dari persentase ketuntasan yang diharapkan yakni $80 \%$. Pada siklus II hasil belajar siswa dikatakan tuntas karena siswa yang memperoleh nilai $\geq 70$ sebesar $87,3 \%$ sudah melebihi persentase ketuntasan yang diharapkan yaitu $80 \%$

\section{DAFTAR PUSTAKA}

Undang - undang Republik Indonesia No. 20 Tahun 2003 Tentang Sistem Pendidikan Nasional.

Rukmini, Sri. 2004. Perkembangan Anak dan Remaja. Jakarta: PT. Rineka Cipta.

Saripudin W., Udin. 1989. Konsep dan Masalah Pengajaran Ilmu Pengetahuan Sosial di Sekolah Menengah. Jakarta: LPTK.

Suprijono, Agus. 2009. Cooperative Learning Teori dan Aplikasi PAIKEM. Pustaka Pelajar. Yokyakarta. 